\title{
MAMMALS OF WAPUSK NATIONAL PARK : Survey Results and a Provisional Checklist
}

JACK DUBOIS, Wildlife \& Ecosystem Protection Branch, Manitoba Conservation, Box 24 - 200 Saulteaux Crescent, Winnipeg. MB R3J 3W3; KIM MONSON, Geography Department, University of Winnipeg, 515 Portage Avenue, Winnipeg, MB R3B 2E9

In 1997, staff of the Manitoba Museum and the newly created Wapusk National Park began planning a small mammal inventory of the park. The rationale was straightforward - to manage the park, Wapusk staff need to know what is out there. Fieldwork started in 1998 and continued through the following three field seasons with the primary objective of producing a credible list of the mammals of Wapusk. A secondary objective was to provide the Museum with voucher specimens of several species from known locations to demonstrate habitat affiliations within the park.

During fieldwork, larger species were observed opportunistically, along with their tracks and signs. Seasonal Park Officer Jack Batstone of Churchill MB was interviewed in 1998 regarding local medium and large mammal species because of his extensive experience in the area as a trapper, hunter and resident. Fur records for 1996 - 2000 for the registered trap lines within the park were obtained from Manitoba Department of Conservation (D. Berezanski, pers. comm.). Some conversations were held with York Landing First Nation people about their traditional knowledge of mammal species in the area, but more work is needed in this area to get a complete picture.

The habitats in the Park and nearby region provide unique and significant contributions to the biodiversity of Manitoba and Canada. ${ }^{7}$ Among the unique features, as examples, are the largest Polar Bear denning area in the world; the only North American Ross' Gull nesting area; large nesting concentrations of Canada and snow geese; an intersection of the range of plant and animal species from the north, south, east and west; and two unique caribou herds. This area has been proposed for both an Important Bird Areas site and Western Hemisphere Shorebird Network site.

Although a wide variety of biological investigations have occurred and continue at Churchill, only a few species - e.g. Lesser Snow Geese, Canada Geese, and Polar Bears - have been studied extensively in the area that is now Wapusk National Park..$^{6,11,13,20}$ Only a few studies investigated other mammalian fauna. ${ }^{1,4,8,10}$ Earlier small mammal inventory work was done in the vicinity of Churchill and at the mouth of the Seal River by museum field parties, using the same methods, in the early $1970 \mathrm{~s}^{23}$ Subsequent to that, museum staff collected small mammals at York Factory in 1975 and at the mouth of Opoyastin Creek in 1982.

During this study, the following sites were sampled for small mammals: near the mouth of the Broad River, $58^{\circ} 08^{\prime} \mathrm{N}, 92^{\circ} 51^{\prime} \mathrm{W}$, (2226 July 1998); along the length of the Owl River within Wapusk National Park (10-20 June 1999); near the mouth of the Owl River, $57^{\circ} 51^{\prime} \mathrm{N}, 92^{\circ} 45^{\prime} \mathrm{W},(21-27$ July 1999; June 27-July 12000 ; 3-7 August 2001); Hannah Lake, $58^{\circ} 22^{\prime} \mathrm{N}, 93^{\circ} 26^{\prime} \mathrm{W}$, (29 June-1July 2001); Brown Lake vicinity, 58 $24^{\prime} \mathrm{N}$, 933' W, (1-3 July 2001) (Fig. 1). 


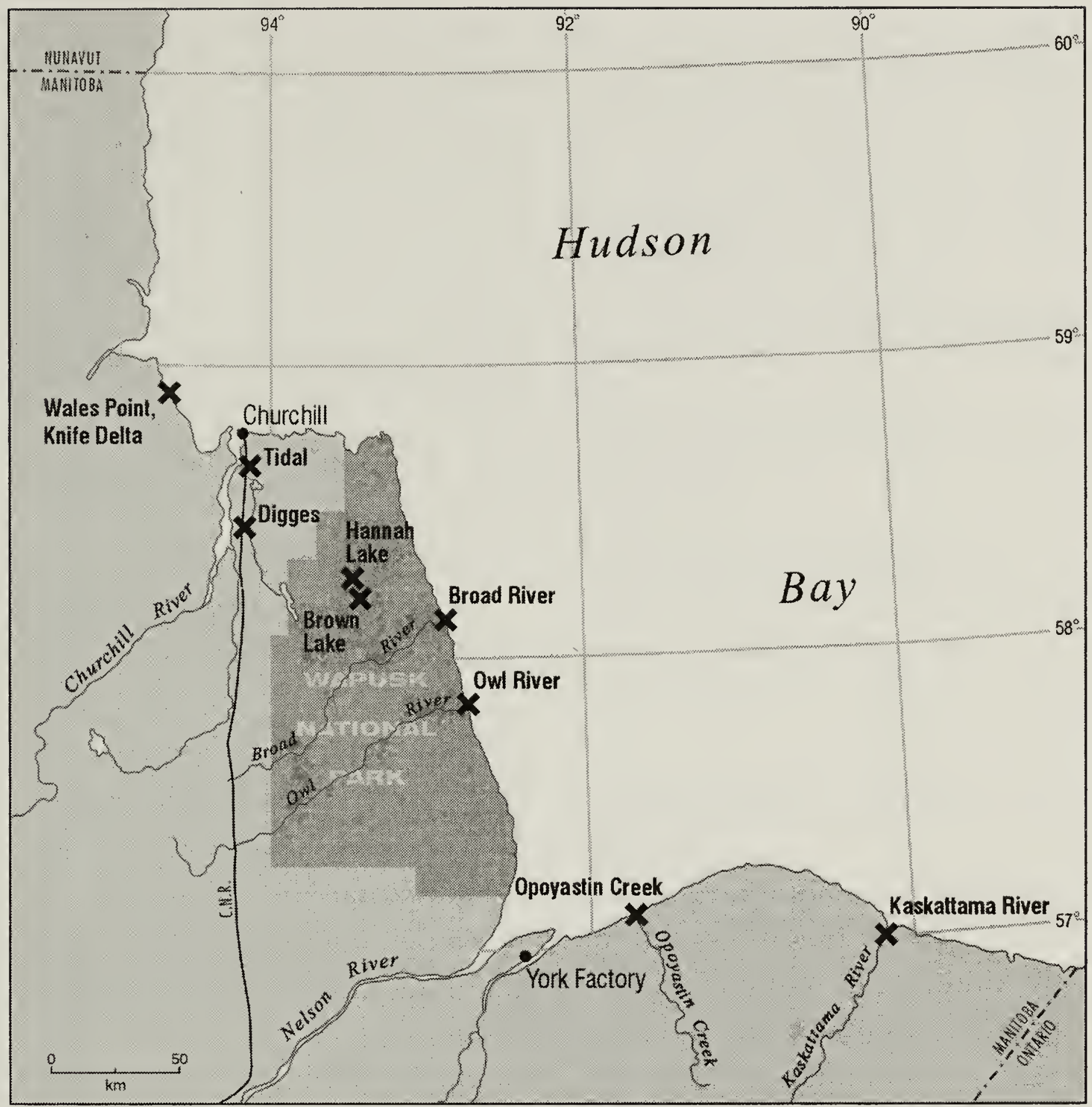

Figure 1. Locations at which surveys for mammals were conducted in the area of Wapusk National Park

Local habitats were sampled using Museum Special ${ }^{\circledR}$ traps, under Parks Canada research permits to the senior author. Sites included all representative habitats readily accessible within the time available. Immediately along the coast, such habitats include small, patchy beach meadows; sedge-meadows; lichen-heath tundra along water bodies in inter-beach ridge swales, i.e., pond margins, shrubby pond, river and creek margins. During the Owl River traverse from the Hudson Bay rail line to the bay itself, some sampling was done in treed areas within $250 \mathrm{~m}$ of the shoreline. Along the Owl River and at its estuary, Richardson's Collared Lemming was particularly sought after, so its preferred habitat of dry lichenheath tundra was disproportionately sampled. ${ }^{18}$ Exact locations of all trap lines were recorded in UTM co-ordinates by handheld Global Positioning System (GPS) units. These data have been entered into the Wapusk Geographic Information System, housed in the Prairie and Northern Region, Parks Canada offices in Winnipeg, to link each species with the vegetation map of the Park (Brook 2001). ${ }^{5}$ All suitable mammal specimens collected were prepared in the field as study skins and skulls, and then deposited in the collection of the Manitoba Museum. 


\section{Results}

In total, 13 species were captured. Twelve additional species were observed. Weather, drought and time of year influenced trap success. Capture rates during this study straddled high (1999), crash (2000) and recovery (2001) years in the population cycle of small mammals of the region. This highlights the challenge of working with small mammals and the value of long-term monitoring in areas such as the Hudson Bay coastal region in the face of the well-known biological cycles. ${ }^{19}$ All species at these latitudes have only one litter per year, so the later in summer that collecting occurs, the larger the population of small mammals to sample from. Most of the females captured during this study were pregnant, in oestrus or had given birth recently. Few young of the year were taken.

The Richardson's Collared Lemmings taken at the Owl River are $100 \mathrm{~km}$ south of the closest recorded occurrence, and thus represent a southern range extension for this species. ${ }^{1}{ }^{16}$ Elders of the York Landing First Nation say that the collared lemmings, referred to as "polar bear lemmings" because their fur turns white in the winter, were found even further south at one time (Flora Beardy, pers. comm). The coastal region, from Wapusk National Park to the Ontario border, was part of the First Nation's traditional use area for many generations. ${ }^{3}$ An examination of the vegetation classification map indicates that there may well be suitable habitat for collared lemming in Wapusk National Park south of those locations reported here. ${ }^{5}$ Further fieldwork is needed.

A survey of the literature, ${ }^{2,9}$ discussions with a local trapper, examination of trap line returns, and this study revealed that there are at least 41 mammal species inhabiting Wapusk National Park and adjacent waters, and 12 additional hypothetical species (see Check List, below). Only two species have been locally extirpated since Europeans first came to the region more than 300 years ago - the tundra grizzly and the Muskox, although one grizzly was seen in the Broad River area in 1998 (D. Clarke, pers. comm) and in 2003 (D. Hedman, pers. comm). The last wild Muskoxen reported in Manitoba were two individuals seen in the area of Wapusk National Park in the summer of $1897 .{ }^{14}$ Bowhead Whales reappeared in the Churchill River mouth vicinity recently, after an absence of about a century, ${ }^{21}$ and were seen as recently as August 2002 (C. Elliott, pers. comm). Minke Whales were seen in Button Bay in 1991, but have not been seen since. ${ }^{12}$

If global climate change occurs as predicted, the flora and fauna of the Hudson Bay coastal region may exhibit "rapid" changes in distribution, given that several species are at or near range limits now. ${ }^{15}$ The range of Arctic species, such as Polar Bear, ${ }^{20}$ lemming and Arctic Hare, would shrink northward, with those of southern species, like Deer Mouse, White-tailed Deer and Striped Skunk expanding northward behind them. Given the well-known role of the latter three species as vectors of a variety of diseases, their range expansion could exacerbate negative climate change impacts on northern ecosystems. ${ }^{22}$ Periodic monitoring of mammal distribution should be part of any regional climate- change monitoring program.

\section{Acknowledgements}

On behalf of the Museum team we would like to thank Parks Canada for financial and logistical support and the staff of the Churchill Northern Studies Centre for their excellent logistical support. Manitoba Conservation, Manitoba Hydro and Environment Canada, through the Habitat Stewardship Program, also supported fieldwork in the last three years. We thank Wapusk National Park for lending us various equipment over the years, as well providing accompanying park officers. Staff of Hudson Bay Helicopters always gave excellent, 
friendly service. Many thanks to Janis Klapecki and volunteer David Wright for their invaluable assistance. Thanks to Elizabeth Punter, Jack Batstone, Greg Lundie, Ryan Brook, Evan Richardson and Joerg Tews for their cheerful company and support in the field.

1. BAHR, J. 1989. The Hunting Ecology of Arctic Foxes (Alopex lagopus) Near Cape Churchill. Manitoba. MSc. Thesis, Zoology Department, University of Manitoba, Winnipeg, MB

2. BANFIELD, A. 1973. The Mammals of Canada. National Museum of Canada, Ottawa 438 pp.

3. BEARDY, F., and R. COUTTS. 1996. Voices From Hudson Bay. McGill-Queens Press, Montreal \& Kingston. $158 \mathrm{pp}$.

4. BROKX, P.A.J. 1965. The Hudson Bay Lowland as Caribou Habitat. MSc Thesis, University of Guelph, Guelph, ON

5. BROOK, R.K. 2001 Structure and dynamics of the vegetation in Wapusk National Park and the Cape Churchill Wildlife Management Area of Manitoba: Community and Landscape Scales. Master of Natural Resource Management Thesis, University of Manitoba, Winnipeg, MB. 265 pp.

6. COOKE, F., R.F.ROCKWELL, and D. B. LANK. 1995. The Snow Geese of La Perouse Bay. Oxford University Press. 297 pp.

7. DREDGE, L.A. 1992. Field Guide To The Churchill Region Manitoba. Geological Survey of Canada, Miscellaneous Report 53.

8. ELLIOTT, C. 1998. Cape Churchill Caribou: Status of Herd and Harvest 1997/98. Manuscript Report No. 98-05. Manitoba Natural Resources, Winnipeg.

9. HALL, RE. 1981. The Mammals of North America. J. Wiley \& Sons, Toronto.

10. MOSER, T.J., and RUSCH, D.H. 1988. Notes on uncommon birds and mammals near Cape Churchill, Manitoba. Blue Jay 46:52-54.

11. PAKALUK, A.J. 1969. Nesting Ecology of Canada Geese of the Churchill Area, Northern Manitoba. MSc. Thesis, Colorado State University. 134 pp.
12. PATTIE, D.L., and M. WEBBER. 1992. First record of the Minke Whale, Balaenoptera acutorostrata, in Manitoba waters. Canadian Field-Naturalist 106(2): 266-267.

13. POSTON, B., D. M. EALEY, P.S.TAYLOR, and G. B. MCKEATING. 1990. Priority Migratory Bird Habitats of Canada's Prairie Provinces. Canadian Wildlife Service. $107 \mathrm{pp}$.

14. PREBLE, E.A. 1902. A biological investigation of the Hudson Bay region. North American Fauna 32: 3973.

15. RIZZO B., and W. WIKEN. 1992. Assessing the sensitivity of Canada's ecosystems to climate change. Climate Change 21:37-55.

16. ROTH, J.D. 2002. Temporal variability in arctic fox diet as reflected in stable-carbon isotopes; the importance of sea ice. Oecolgia 133: 70-77

17. ROTH, J.D. 2003 Variability in marine resources affects arctic fox population dynamics. Journal of Animal Ecology 2003 72: 668-676

18. SCOTT, P.A., and R.I. HANSELL. 1989. The lemming community on the lichen-heath tundra at Churchill, Manitoba. Canadian Field-Naturalist 103(3):358-362.

19. SCOTT, P.A. 1993. Relationship between the onset of winter and collared lemming abundance at Churchill, Manitoba, Canada: 1932-90. Arctic 46(4)293-296.

20. STIRLING, I., N.J. LUNN, and J. IACOZZA. 1999. Long-term trends in the population ecology of polar bears in western Hudson Bay in relation to climate change. Arctic 52:294-306.

21. WATTS, P.D. 1988. Bowhead whale Balaena mysticetus sightings off the coast of Manitoba. Canadian Field-Naturalist 102(3):538-539.

22. WILLIAMS, E.S., and I.K. BARKER. 2001. Infectious Diseases of Wild Mammals. Iowa State University Press, Ames.

23. WRIGLEY, R.E. 1974. Ecological notes on animals of the Churchill region of Hudson Bay. Arctic 27:201214. 